\title{
Haematological reference intervals of sows at end gestation in ten French herds, the impact of parity on haematological parameters and the consequences on reproductive performance
}

\author{
Gwenaël Boulbria ${ }^{1,2^{*}}$ (D) Charlotte Teixeira Costa ${ }^{1}$, Valérie Normand ${ }^{1,2}$, Véronique Bachy ${ }^{3}$, Daphné Rochel ${ }^{3}$,
} Mathieu Brissonnier ${ }^{1}$, Pauline Berton ${ }^{1}$, Franck Bouchet ${ }^{1,2}$ and Arnaud Lebret ${ }^{1,2}$

\begin{abstract}
Background: Changes in haematological values occur during the reproductive cycle. In veterinary swine practice, haematological reference intervals for this period are scarce. Over past decades, there has been a remarkable increase in reproductive prolificacy, possibly making previously established haematological reference intervals for sows outdated.

Objectives: The aim of this study was to provide updated haematological reference intervals for sows at endgestation, to study the influence of parity on those haematological parameters and to evaluate the impact of haemoglobin levels on production performance.

Methods: The data presented in this article were obtained using blood samples from 198 apparently healthy and conventionally managed group-housed sows at end-gestation from ten breeding herds located in France. The samples were analysed for haematological variables using impedance technique on Horiba ABX analyser (Horiba, Kyoto, Japan). The reference intervals were calculated according to the guidelines of The American Society for Veterinary Clinical Pathology using SUMMARY procedure in R Studio. Analysis of variance (ANOVA) models were used to evaluate the influence of parity on each haematological parameter and the impact of haemoglobin values on production performances at farrowing. Differences were considered as significant if $p<0.05$.
\end{abstract}

\footnotetext{
* Correspondence: g.boulbria@porc.spective.fr

'Porc.Spective Swine Vet Practice, ZA de Gohélève, rue Joseph et Étienne Montgolfier, 56920 Noyal- Pontivy, France

${ }^{2}$ Rezoolution Pig Consulting Services, ZA de Gohélève, rue Joseph et Étienne Montgolfier, 56920 Noyal- Pontivy, France

Full list of author information is available at the end of the article
}

C C The Author(s). 2021 Open Access This article is licensed under a Creative Commons Attribution 4.0 International License, which permits use, sharing, adaptation, distribution and reproduction in any medium or format, as long as you give appropriate credit to the original author(s) and the source, provide a link to the Creative Commons licence, and indicate if changes were made. The images or other third party material in this article are included in the article's Creative Commons licence, unless indicated otherwise in a credit line to the material. If material is not included in the article's Creative Commons licence and your intended use is not permitted by statutory regulation or exceeds the permitted use, you will need to obtain permission directly from the copyright holder. To view a copy of this licence, visit http://creativecommons.org/licenses/by/4.0/. The Creative Commons Public Domain Dedication waiver (http://creativecommons.org/publicdomain/zero/1.0/) applies to the data made available in this article, unless otherwise stated in a credit line to the data. 


\begin{abstract}
Results: Reference intervals produced in this study were similar to previously published references but we noticed marked differences in white blood cell values. The study of the impact of parity revealed significant changes for gilts and parity $5+$ sows regarding haematological values. Gilts had higher red and white blood cells counts, haemoglobin values and haematocrit values. Regarding haemoglobin values, the higher the number of liveborn and weaned piglets per litter, the lower the haemoglobin value at end-gestation. For sows of fifth or higher gestation, we found that the higher the percentage of stillborn piglets, the lower the haemoglobin value at endgestation.

Conclusions: This study provides haematological reference intervals for sows at end-gestation. These will be useful for swine veterinarians and researchers for a better understanding of the influence of parity on haematological parameters and haemoglobin values and their relation to reproductive performance.
\end{abstract}

Keywords: Pig, Blood, Haematology, Reference interval, Haemoglobin

\section{Background}

Despite their wide availability, haematological values are rarely used in practice for the evaluation of sow health and its potential consequences on reproductive performance. Up to now, very few haematological variables have been used in swine practice because of the limited availability of reference intervals [1]. Moreover, over past decades, there has been a marked increase in litter size and reference intervals that were previously established may now be outdated. Haematological parameters play a significant role on swine reproductive performance. In particular, the impact of low haemoglobin concentration on the risk of stillborn piglets [2] has already been demonstrated. Haematological values of swine are influenced by pathological processes and by a wide range of environmental and physiological factors including diet, age, sex, housing and management practices [3]. Many infectious agents can cause changes in white blood cell (WBC) counts, as well as red blood cell (RBC) counts, haemoglobin concentration $(\mathrm{Hb})$ and haematocrit $(\mathrm{Hct})$, depending on the severity of clinical signs and magnitude of the immune response [4]. Commonly cited agents inducing changes in haematological parameters in pigs are infection with Mycoplasma suis causing anaemia [5] and the porcine reproductive and respiratory syndrome (PRRS) virus causing a depletion of WBC [6].

The measurement of haematological parameters in sows can serve as a practical tool for assessing pathological conditions and reflect metabolic disturbances caused by inappropriate feeding or nutritional deficiencies. Several studies have investigated the influence of age and stage of gestation on the variability of blood values $[4,7,8]$. Indeed, physiological differences in haematological parameters have been observed depending on the parity of the sow and litter size, with an increased litter size associated with anaemia [9]. The aim of this study was to produce haematological reference intervals for sows at end-gestation. The second objective was to evaluate the influence of parity on haematological values and to provide an overview of the impact of haemoglobin concentration on reproductive performance.

\section{Materials and methods}

\section{Farms and animals}

Blood samples were collected five to twelve days before farrowing from 199 sows belonging to two farrow-towean and eight farrow-to-finish farms in Brittany (France). Selected herds were epidemiologically unrelated (different nucleus herds for gilts and different food suppliers). The breed of the sows was either Large White $\mathrm{x}$ Landrace (eight farms) or Large White $\mathrm{x}$ Landrace $\mathrm{x}$ Tai Zumu (two farms). Farms were also selected for the absence of infectious outbreaks in sows or suckling piglets and the absence of collective antibiotic treatments of sows in the last six months prior to the study. At sampling time, sows were group-housed in indoor facilities in accordance with the European Union legislation and were free from clinical disease based on veterinary observation. Herds were enrolled and all samples and data were collected between December 2017 and March 2018. Farm status regarding PRRSV and PCV-2 is presented in Table 1. PRRSV status has been determined according to the AASV classification [10]. All positive stable herds were vaccinated with modified live vaccines. Finally, for each farm, parasitic status was unknown. On each farm, 20 sows from the same batch were sampled 12 to 5 days before farrowing. In one herd, only 19 sows could be sampled. The samples were stratified on the basis of gestation rank: 4 to 6 pregnant gilts, 3 to 6 sows in second gestation, 3 to 6 sows in third or fourth gestation and 4 to 9 sows in fifth or higher gestation.

\section{Blood sample collection and analyses}

Sows were restrained using a wire nose snare. Blood samples $(5 \mathrm{ml})$ were obtained by venipuncture of the jugular vein and collected into EDTA tubes. Blood 
Table 1 Farm status regarding main diseases affecting haematological parameters

\begin{tabular}{lllll}
\hline Farm & $\begin{array}{l}\text { PRRSV } \\
\text { status [10] }\end{array}$ & $\begin{array}{l}\text { PRRSV } \\
\text { vaccination }\end{array}$ & $\begin{array}{l}\text { PCV-2 gilts } \\
\text { vaccination }\end{array}$ & $\begin{array}{l}\text { PCV-2 multiparous } \\
\text { vaccination }\end{array}$ \\
\hline 1 & Negative & - & Yes & No \\
2 & $\begin{array}{l}\text { Positive } \\
\text { stable }\end{array}$ & Yes & No & No \\
3 & $\begin{array}{l}\text { Positive } \\
\text { stable }\end{array}$ & Yes & Yes & No \\
4 & Negative & - & No & No \\
5 & $\begin{array}{l}\text { Positive } \\
\text { stable }\end{array}$ & Yes & Yes & Yes \\
6 & Negative & - & No & No \\
7 & Negative & - & No & No \\
8 & $\begin{array}{l}\text { Positive } \\
\text { stable }\end{array}$ & Yes & No & No \\
9 & Negative & - & Yes & Yes \\
10 & $\begin{array}{l}\text { Positive } \\
\text { stable }\end{array}$ & Yes & No & No \\
\hline
\end{tabular}

samples were stored under positive cold conditions until submission to the diagnostic laboratory Orbio (Finalab, Bron, France) within $24 \mathrm{~h}$. Standard haematological evaluations were performed using the impedance technique on a Horiba ABX analyser (Horiba, Kyoto, Japan). The following haematological variables were measured: red blood cells (RBC) count, haematocrit (Hct), haemoglobin concentration $(\mathrm{Hb})$, mean corpuscular volume (MCV), mean corpuscular haemoglobin $(\mathrm{MCH})$, mean corpuscular haemoglobin concentration $(\mathrm{MCHC})$, platelet count (PLT), white blood cells (WBC) count, and differentiation of neutrophils (absolute count and percentage), eosinophils (absolute count and percentage), monocytes (absolute count and percentage) and lymphocytes (absolute count and percentage).

\section{Performance data collection}

Numbers of total born, number of stillborn piglets and number of piglets weaned per sow were recorded by the farmer. Piglets were considered stillborn by visual judgement of the farmer and corresponded to dead piglets collected during or immediately after farrowing. No necropsy of stillborn piglets was performed.

\section{Statistical analysis}

The reference intervals were calculated according to the guidelines of the American Society for Veterinary Clinical Pathology [11] (ASVCP) using the SUMMARY procedure in RStudio. Each of the variables was checked for the presence of extreme outliers and those outliers were removed from the analysis. Next, the data were submitted to reference limit evaluations. The $95 \%$-percentile reference intervals method (2.5th and 97.5th percentile) was used to determine the reference intervals as recommended by ASVCP for a sample size over 120 . The reference intervals with $90 \%$-confidence limits were calculated with Reference Value Advisor (V.2.1) [12] freeware in Excel (Microsoft Corporation, Redmond, USA). Then, ANOVA models were used to evaluate the influence of farm and parity for each haematological parameter and the impact of haemoglobin values on production performances at farrowing. The statistical analyses were carried out using RStudio version 4.0.2 (R Core Team, 2020). Differences were considered statistically significant if $p<0.05$.

\section{Results}

A total of 199 sows were sampled, including 49 pregnant gilts, $47 \mathrm{~s}$ parity sows, 52 third or fourth parity sows and 51 sows with parity five or higher. One sow was excluded from the study because haematological measures were not possible due to sample haemolysis, so that a total of 198 sows were included in the analysis in order to produce the reference intervals presented hereafter. For each criterion, the number of outlier values removed to produce reference intervals is presented in Table 2.

\section{Reference intervals for 198 end-gestation sows}

Based on a non-parametric test regarding individual blood samples, the time between sampling and farrowing, the farm were set as a random effect. The reference intervals (RI) for $\mathrm{RBC}, \mathrm{WBC}$ and platelets are listed in Table 3. We compared mean haematological values from our study with previously published RIs in Table 4. We noticed some marked differences $(>10 \%)$, with lower WBC counts and the percentage of lymphocytes, and a higher percentage of neutrophils in our study.

Influence of parity rank on haematological parameters Mean, minimum and maximum reference values per parity rank are presented in Table 5. Mean $\mathrm{RBC}, \mathrm{Hb}$, Hct, WBC and PLT values were significantly higher in gilts, while mean $\mathrm{MCV}$ and $\mathrm{MCH}$ values were significantly lower. Mean haematological values of sows in parity 5 or higher were also significantly different from other parity ranks for $\mathrm{RBC}, \mathrm{MCV}, \mathrm{MCH}, \mathrm{MCHC}, \mathrm{WBC}$ and PLT.

\section{Impact of haemoglobin concentration on farrowing performance parameters}

In the studied population, sows had an average of 14.9 liveborn piglets and 12.9 weaned piglets per litter. Concerning associations between haemoglobin concentration and farrowing performance, a significant inverse 
Table 2 Number of values included for reference intervals after the removal of outliers

\begin{tabular}{lccc}
\hline Variables & $\begin{array}{l}\text { Number of } \\
\text { values }\end{array}$ & $\begin{array}{l}\text { Number of } \\
\text { outliers }\end{array}$ & $\begin{array}{l}\text { Number of values included for } \\
\text { reference intervals }\end{array}$ \\
\hline RBC & 198 & 4 & 194 \\
Hb & 198 & 6 & 192 \\
HCT & 198 & 1 & 197 \\
MCV & 198 & 0 & 198 \\
MCH & 198 & 3 & 195 \\
MCHC & 198 & 3 & 195 \\
WBC & 198 & 1 & 197 \\
Neutrophils & 198 & 1 & 197 \\
Eosinophils & 198 & 2 & 196 \\
Monocytes & 198 & 1 & 197 \\
Lymphocytes & 198 & 2 & 196 \\
PLT & 198 & 0 & 198 \\
\hline
\end{tabular}

$\mathrm{N}$ indicates number of animals, $R /$ reference interval, $R B C$ red blood cell count, WBC white blood cell count, $\mathrm{Hb}$ haemoglobin, $\mathrm{HCT}$ haematocrit, $\mathrm{MCV}$ mean corpuscular volume, $\mathrm{MCH}$ mean corpuscular haemoglobin, $\mathrm{MCHC}$ mean corpuscular haemoglobin concentration, PLT platelet count

relationship was observed; the higher the number of liveborn piglets, the lower the haemoglobin value at endgestation, regardless of parity rank (Fig. 1). We observed the same relationship between haemoglobin concentration and number of weaned piglets per litter.

In the studied population, an average of $6.7 \%$ of piglets were stillborn. This percentage was relatively low compared to the average in France $(7.4 \%$ in 2018). For sows in their fifth or higher gestation, the lower the haemoglobin value at end-gestation, the higher the percentage of stillborn piglets $(p=0.002)$ (Fig. 1). For the other parity ranks, the difference was not significant.

\section{Discussion}

Assuming that haematological data undergo constant change due to genetic progress and an increase in litter size, the aims of this study were to propose updated RI for French sows at end-gestation, to study the impact of parity ranks on haematological parameters and to determine whether haemoglobin concentration has an influence on performance parameters at farrowing.

We sampled 199 sows, a population size consistent with previous studies. In this study, samples were obtained by venipuncture at the jugular vein, the most common sampling site in practice. Porcine $\mathrm{RBC}$ are relatively fragile and turbulence or improper handling of the sample frequently results in haemolysis [13]. In our study, blood samples were immediately stored under positive cold conditions and sent to the laboratory within $24 \mathrm{~h}$. Using this protocol, only one sample was excluded because of haemolysis. We determined RIs according to the ASVCP guidelines, and the final sample size was amply sufficient to establish these $[11,14]$.

Haematological reference intervals can vary according to breed [15], season [13], physiological status [4], age [4], management factors [4] and laboratory measurement techniques. We randomly selected ten different herds that were epidemiologically unrelated and had different

Table 3 Reference intervals for 198 clinically healthy sows at end-gestation in ten French herds

\begin{tabular}{|c|c|c|c|c|c|c|c|c|}
\hline \multirow[t]{2}{*}{ Variables } & \multirow[t]{2}{*}{ Unit } & \multirow[t]{2}{*}{$\mathbf{N}$} & \multirow[t]{2}{*}{ Mean } & \multirow[t]{2}{*}{ Median } & \multirow[t]{2}{*}{ SD } & \multirow{2}{*}{$\begin{array}{l}\text { Range } \\
\text { (min- } \\
\text { max) }\end{array}$} & \multicolumn{2}{|c|}{ RI with $90 \%$ Confidence Interval (CI) } \\
\hline & & & & & & & Lower limit of $\mathrm{Cl}^{\mathrm{a}}$ & Upper limit of $\mathrm{Cl}^{\mathrm{a}}$ \\
\hline$\overline{\mathrm{RBC}}$ & $10^{12} / \mathrm{L}$ & 198 & 5.8 & 5.8 & 0.7 & $3.49-7.75$ & $4.3(4.0-4.7)$ & $7.2(6.9-7.4)$ \\
\hline $\mathrm{Hb}$ & $\mathrm{g} / \mathrm{dL}$ & 198 & 12.1 & 12.1 & 1.2 & 7.7-15.4 & $9.4(8.6-10.2)$ & $14.5(8.6-10.2)$ \\
\hline $\mathrm{HCT}$ & $\%$ & 198 & 39.7 & 39.6 & 4.6 & $11.6-54.8$ & $30.9(24.7-32.5)$ & $48.6(46.4-50.1)$ \\
\hline MCV & $\mathrm{fl}$ & 198 & 68.6 & 68.0 & 3.3 & $60-77$ & $61.0(60.0-63.0)$ & $75.0(74.0-76.0)$ \\
\hline $\mathrm{MCH}$ & $\mathrm{pg}$ & 198 & 21.0 & 20.9 & 1.2 & $17.4-24.7$ & $18.2(17.8-19.0)$ & $23.2(23.1-24.4)$ \\
\hline $\mathrm{MCHC}$ & $\mathrm{g} / \mathrm{dL}$ & 198 & 30.5 & 30.6 & 0.9 & $24.5-33.6$ & $29.1(26.2-29.4)$ & $31.8(31.6-33.5)$ \\
\hline WBC & $10^{9} / \mathrm{L}$ & 198 & 12.1 & 11.9 & 2.7 & $3.1-22.3$ & $7.6(4.1-8.3)$ & $18.8(17.1-19.3)$ \\
\hline \multirow[t]{2}{*}{ Neutrophils } & $10^{9} / \mathrm{L}$ & 198 & 7.2 & 7.0 & 1.8 & $0.3-14.4$ & $3.5(0.4-4.8)$ & $11.9(10.7-12.9)$ \\
\hline & $\%$ & 198 & 59.3 & 60.4 & 8.2 & $7.7-76.7$ & $47.7(11.6-49.6)$ & $72.0(69.7-74.0)$ \\
\hline \multirow[t]{2}{*}{ Eosinophils } & $10^{9} / \mathrm{L}$ & 198 & 1.0 & 0.9 & 0.5 & $0-2.6$ & $0.3(0-0.3)$ & $2.2(1.9-2.4)$ \\
\hline & $\%$ & 198 & 7.7 & 7.1 & 3.4 & $0.4-17$ & $2.9(0.5-3.3)$ & 15.7 (13.9-16.4) \\
\hline \multirow[t]{2}{*}{ Monocytes } & $10^{9} / \mathrm{L}$ & 198 & 0.6 & 0.6 & 0.2 & $0.1-1.5$ & $0.3(0.2-0.4)$ & $0.9(0.9-1.1)$ \\
\hline & $\%$ & 198 & 4.8 & 4.8 & 0.9 & $1.9-8.3$ & $3.3(2.8-3.6)$ & $6.8(6.2-7.3)$ \\
\hline \multirow[t]{2}{*}{ Lymphocytes } & $10^{9} / \mathrm{L}$ & 198 & 3.3 & 3.3 & 0.9 & $1.3-6.7$ & $1.9(1.7-1.9)$ & $5.6(5.1-6.1)$ \\
\hline & $\%$ & 198 & 28.2 & 27.4 & 8.3 & $10.3-83.5$ & $17.3(16.1-19.1)$ & $40.5(37.5-82.0)$ \\
\hline PLT & $10^{9} / \mathrm{L}$ & 198 & 225.8 & 221.5 & 74.5 & $42-441$ & 90.7 (72-109) & $400.7(346-434)$ \\
\hline
\end{tabular}

$\mathrm{N}$ indicates number of animals, $R /$ reference interval, $R B C$ red blood cell count, WBC white blood cell count, $H b$ haemoglobin, $H C T$ haematocrit, $M C V$ mean corpuscular volume, $\mathrm{MCH}$ mean corpuscular haemoglobin, $M C H C$ mean corpuscular haemoglobin concentration, PLT platelet count

${ }^{a}$ using 2.5 th to 97.5 th inter-percentile range 
Table 4 Mean haematological variables of our study compared with the literature

\begin{tabular}{|c|c|c|c|c|c|}
\hline Variables & Unit & Mean & Thorn CE., 2010 [2] & $\begin{array}{l}\text { Ježek et al., } 2018 \\
\text { [3] }\end{array}$ & Bhattarai et al., 2019 [4] \\
\hline Stage & & $\begin{array}{l}5-12 \text { days before } \\
\text { parturition }\end{array}$ & $\begin{array}{l}2 \text { weeks or less before } \\
\text { parturition }\end{array}$ & Gestation & $\begin{array}{l}\text { Mid-gestation (between } 56-70 \text { days of } \\
\text { gestation) }\end{array}$ \\
\hline$\overline{\mathrm{RBC}}$ & $\begin{array}{l}10^{12} / \\
L\end{array}$ & 5.8 & 5.7 & 5.62 & 6.14 \\
\hline $\mathrm{Hb}$ & $\mathrm{g} / \mathrm{dL}$ & 12.1 & 12.6 & 11.6 & 12.03 \\
\hline $\mathrm{HCT}$ & $\%$ & 39.7 & 40.0 & 34.9 & - \\
\hline MCV & $\mathrm{fl}$ & 68.6 & 70.0 & 62.2 & 63.4 \\
\hline $\mathrm{MCH}$ & $\mathrm{pg}$ & 21.0 & - & 20.6 & - \\
\hline $\mathrm{MCHC}$ & $\mathrm{g} / \mathrm{dL}$ & 30.5 & 31.6 & 33.2 & 31.04 \\
\hline WBC & $10^{9} / \mathrm{L}$ & 12.1 & 15.6 & 15.21 & 15.44 \\
\hline Neutrophils & $\%$ & 59.3 & 39.0 & - & 38.4 \\
\hline Eosinophils & $\%$ & 7.7 & 0.7 & 7.0 & 7.4 \\
\hline Monocytes & $\%$ & 4.8 & 6.0 & 1.0 & 4.2 \\
\hline Lymphocytes & $\%$ & 28.2 & 52.0 & 43.0 & 47.8 \\
\hline PLT & $10^{9} / \mathrm{L}$ & 225.8 & - & 274 & - \\
\hline
\end{tabular}

$R B C$ red blood cell count, $H b$ haemoglobin, $H C T$ haematocrit, $M C V$ mean corpuscular volume, $M C H$ mean corpuscular haemoglobin, $M C H C$ mean corpuscular haemoglobin concentration, WBC white blood cell count, $P L T$ platelet count

management practices, so that the population studied could be considered as a representative sampling of French sows. Farm was a significant source of variation for most haematological parameters in a previous study [16], but this was not the case in our study. Similarly, the time lag between sampling and farrowing (5-12 days in our study) was not a variable factor for RIs. All sows were sampled during winter to avoid a seasonal effect. We sampled sows according to parity ranks in order to approximate the demography as described of French herds.

The differences observed between our results and previously published RIs could be explained by several hypotheses. The maximum time between sampling and haematological evaluation was $24 \mathrm{~h}$ in our study and samples were stored immediately under positive cold conditions after sampling until delivery to the laboratory. Routine haemogram values are reported to be stable at $4{ }^{\circ} \mathrm{C}$ for up to $36 \mathrm{~h}$, but the WBC differentials tend to become less reliable after $12 \mathrm{~h}$ of collection [17]. Furthermore, the methodology used to produce RIs could differ from the one used in this study.

Unfortunately, although there is a wide range of RIs for swine today, those involving sows during the same physiological stage are rare; it is therefore difficult to compare our data with those previously described in the literature, mainly because of the gestation stage of sows at sampling time. First, it was described that approximately two weeks before parturition, RBC numbers in sows decrease and continue to do so until the end of

Table 5 Haematological values per parity ranks presented as mean (minimum-maximum)

\begin{tabular}{|c|c|c|c|c|c|}
\hline \multirow[t]{2}{*}{ Variables } & \multirow[t]{2}{*}{ Units } & \multirow{2}{*}{$\begin{array}{l}\text { Gilts } \\
N=49\end{array}$} & \multicolumn{3}{|l|}{ Sows } \\
\hline & & & $\begin{array}{l}\text { Parity } 2 \\
N=47\end{array}$ & $\begin{array}{l}\text { Parity } 3-4 \\
N=52\end{array}$ & $\begin{array}{l}\text { Parity } 5 \text { or more } \\
N=51\end{array}$ \\
\hline $\mathrm{RBC}$ & $10^{12} / \mathrm{L}$ & $6.2(3.5-7.4)^{a}$ & $5.9(4.3-7.8)^{b}$ & $5.7(4.6-7.2)^{b}$ & $5.5(4.1-6.4)^{b}$ \\
\hline $\mathrm{Hb}$ & $\mathrm{g} / \mathrm{dL}$ & $12.5(7.7-15.4)^{\mathrm{a}}$ & $12.2(8.7-14.9)^{a}$ & $11.9(8.6-14.0)^{a}$ & $12.0(9.4-14.5)^{a}$ \\
\hline $\mathrm{HCT}$ & $\%$ & $41.2(24.7-54.8)^{\mathrm{a}}$ & $39.8(30.9-50.1)^{\mathrm{a}}$ & $38.8(11.6-45.8)^{\mathrm{a}}$ & $38.8(30.2-48.3)^{a}$ \\
\hline MCV & $f \mid$ & $62.32(60-73)^{a}$ & $67.97(61-74)^{\mathrm{ab}}$ & $68.71(60-76)^{b}$ & $71.06(66-77)^{c}$ \\
\hline $\mathrm{MCH}$ & $\mathrm{pg}$ & $20.28(17.8-23.2)^{a}$ & $20.86(18.4-24.4)^{a}$ & $20.85(17.4-22.5)^{a}$ & $21.96(20.1-24.7)^{b}$ \\
\hline $\mathrm{MCHC}$ & $\mathrm{g} / \mathrm{dL}$ & $30.53(29.1-31.7)^{\mathrm{ab}}$ & $30.68(27.1-33.6)^{a b}$ & $30.29(30-31.8)^{a}$ & $30.93(29.2-33.5)^{b}$ \\
\hline WBC & $10^{9} / \mathrm{L}$ & $13.9(8.3-22.3)^{a}$ & $12.1(8.2-18.9)^{b}$ & $11.5(3.1-16.7)^{\mathrm{bc}}$ & $10.9(4.1-18.8)^{c}$ \\
\hline PLT & $10^{9} / \mathrm{L}$ & $250.4(115-428)^{a}$ & $240.9(100-323)^{a b}$ & $216.3(72-434)^{\mathrm{ab}}$ & $197.4(42-441)^{b}$ \\
\hline
\end{tabular}

RBC red blood cell count, $H b$ haemoglobin, $H C T$ haematocrit, $M C V$ mean corpuscular volume, $M C H$ mean corpuscular haemoglobin, $M C H C$ mean corpuscular haemoglobin concentration, WBC white blood cell count, PLT platelet count

$a, b, c$ Different letters in superscript within a line means $p<0.05$ 

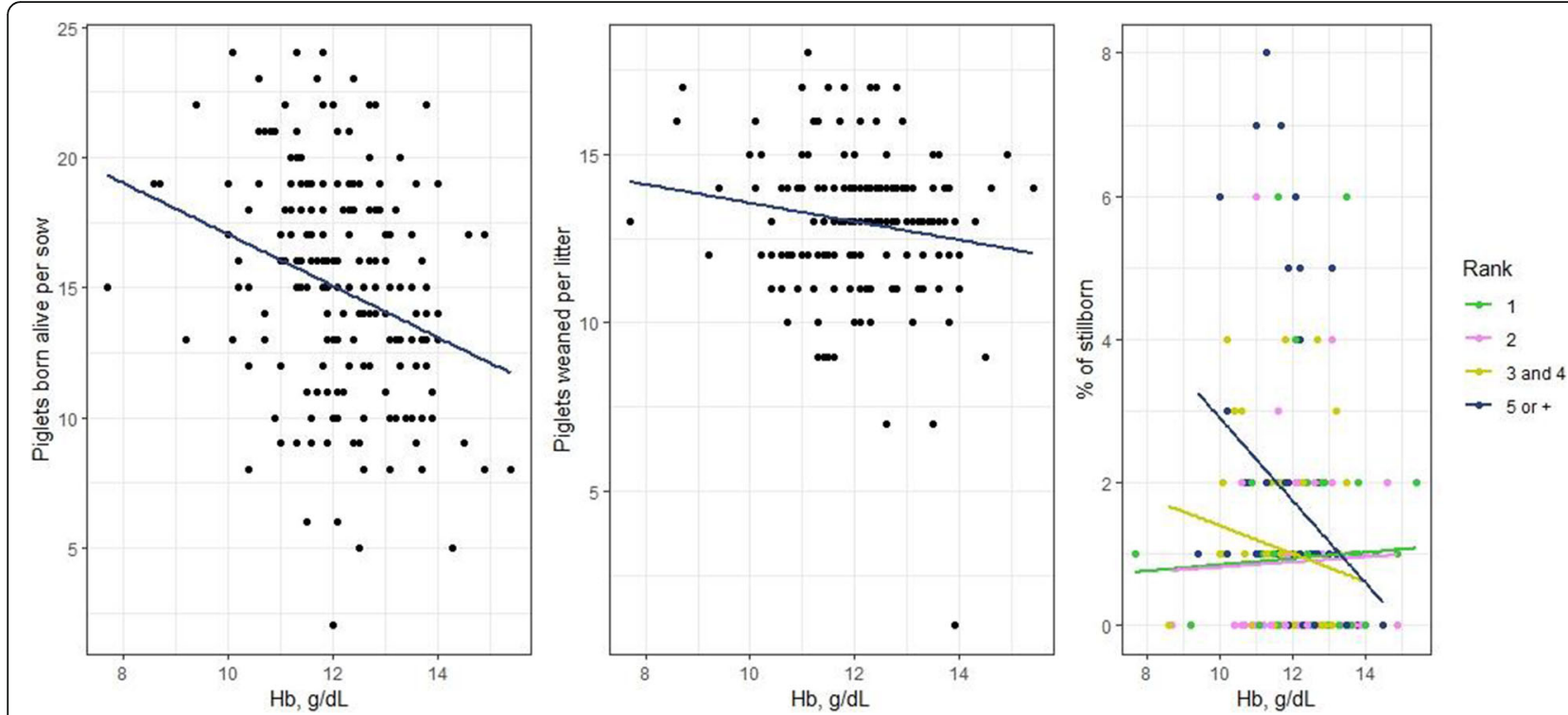

Fig. 1 Correlations between haemoglobin concentration and performance parameters. The blue lines for piglets born alive and pigs weaned per sow indicate there were significant differences between haemoglobin concentration and number of piglets born alive or weaned per sow regardless of parity rank $(p<0.05)$. The blue line for stillbirth in sows or fifth gestation or more indicate also a significant difference $(p<0.05)$

lactation [13]. Secondly, the total WBC number decreases during gestation [13]. For these reasons, comparisons of RIs between studies must be undertaken with care, and take into account the sampling and laboratory protocols and the gestation stage at sampling.

Keeping these limitations in mind, we compared our haematological data with three earlier studies performed by Catherine Thorn [18] (who investigated sows two weeks or less before parturition), by Jožica Ježek [4] (who presented haematological values for 224 pregnant sows) and Sheeva Bhattarai [1] (who studied 248 sows at mid-gestation using the ASVCP guidelines to produce RIs). Even if variations could be observed in both haematologic cell lines, red blood cell composites were found to differ little during gestation compared to white blood cell composites [18]. WBC and leukocyte parameters were previously reported to be closely related to the health status of the sow and the conditions of sampling and samples processing [13]. The increase in WBC may be explained by the high level of neutrophils in our population. Apart from the hypothesis of the poor reliability of WBC count because of the time lag between sampling and analysis, we suspect that stress at the time of sampling might have affected our results. It has been already described in other species like cats and dogs [18]. Stress is one of the factors that can cause neutrophilia and lymphopenia, as observed in our study. Indeed, use of a wire nose snare can cause stress during blood sampling. We sampled three tubes per animal, so each sow was restrained for three to five minutes. Subclinical disease could also have caused an altered WBC count. For example, viral diseases like Porcine Reproductive and Respiratory Syndrome virus [19] and porcine circovirus type 2 (PCV-2) [20] have been associated with lymphopenia in previously published studies. Moreover, neutrophilia has previously been described in pigs infected with PCV-2 [21]. In this study, all sampled sows were clinically healthy and came from PRRSV negative or positive stable herds. Subclinical infection with PCV2 was not assessed during our study which could be a limitation. Finally, the percentage of eosinophils was consistent with that found by Sheeva Bhattarai and Jožica Ježek but we observed a marked difference with Catherine Thorn. In our study, all sows are grouphoused during gestation in accordance with European Union law. Group housing is a risk factor for parasitic infestation (e.g. roundworm), possibly resulting in higher eosinophil counts than those found in older studies.

In this study, we compared the impact of parity ranks on haematological values and we found significant differences for all criteria tested, except for $\mathrm{MCHC}$, between gilts and higher parities. The impact of parity has already been demonstrated for $\mathrm{Hb}$ values in previous studies: $\mathrm{Hb}$ values decreased after first farrowing $[2,9]$. Results presented in the more recent study are consistent with our results for Hct too: Hct values decreased after first parity. Our results highlight the fact that age and parity of sows in particular has an impact on haematological values. Gilts should be considered independently when interpreting haematological results.

In the last part of our study, we focused on the impact of haemoglobin concentration on the reproductive 
performance of sows. Considering only sow's haemoglobin levels could be a limitation. In a Canadian study, no association was observed between stillbirth and the sow's haemoglobin, although an association between the probability of stillbirth and reduced $\mathrm{Hb}$ in piglets was found [22]. In our study, we observed a significant relation between the sow's $\mathrm{Hb}$ and the percentage of stillborn piglets for sows after their fifth or higher gestation. High haemoglobin concentration in the sow's blood may explain the efficiency of uterine contractions and the vigour of the litter at parturition [2]. This might have a positive effect on the number of liveborn piglets. Alternatively, a previous study suggested that a possible explanation for the association between $\mathrm{Hb}$ and stillbirth could be the decrease in oxygen supply to the piglets due to low iron status in the sow [23]. We can compare our results with two previously published studies. The first one showed no relationship between the number of stillborn piglets and haemoglobin values, measured using the rapid HemoCue ${ }^{\ominus} \mathrm{Hb} 201+$ tool [9]. The second study sampled sows at the time of farrowing. They found a significant association between stillbirth and $\mathrm{Hb}$, regardless of the parity of the sows. In the study, all dead piglets collected during farrowing were necropsied to determine whether they were stillborn or not using the lung flotation technique [2]. This was not performed in our study, where stillbirth was based only on the subjective judgement of the farmer.

Other performance parameters at farrowing were analysed in our study. The higher the number of liveborn and weaned piglets, the lower the haemoglobin concentration. Logically, we assumed that the higher is the number of liveborn, the higher the number of weaned piglets, which could explain the relationship between haematological status at late gestation and the number of weaned piglets. A significant link between body reserves and haemoglobin concentration has been demonstrated previously. Regardless of parity rank, haemoglobin concentration was lower in sows with a lower backfat thickness [9]. Unfortunately, in our study, we did not take into consideration body reserves.

\section{Acknowledgements}

The authors would like to thank herd owners for their hospitality and cooperation.

\section{Authors' contributions}

Study conception and design: AL, GB. Data acquisition: GB, AL, VN, MB, FB, PB. Blood analysis: VB, DR. Data analysis and interpretation: $G B, A L, C T C$. Drafting the manuscript: GB, AL, CTC. All authors read, critically revised and approved the final manuscript.

\section{Funding}

The study was financed by Porc.Spective Swine Vet Practice and Finalab Veterinary Laboratories Group.
Availability of data and materials

All datasets used in this study are available from the corresponding author on reasonable request.

\section{Declarations}

\section{Ethics approval and consent to participate}

This study was performed in accordance with the current French national legislation on ethical and welfare recommendations. All samples analysed in this study come from a veterinary practice for general disease diagnosis. No specific authorisation or declaration was needed in this case.

\section{Consent for publication}

All authors gave their consent for publication.

\section{Competing interests}

The authors declare no competing interest.

\section{Author details}

${ }^{1}$ Porc.Spective Swine Vet Practice, ZA de Gohélève, rue Joseph et Étienne Montgolfier, 56920 Noyal- Pontivy, France. ${ }^{2}$ Rezoolution Pig Consulting Services, ZA de Gohélève, rue Joseph et Étienne Montgolfier, 56920 NoyalPontivy, France. ${ }^{3}$ Orbio - Finalab Veterinary Laboratories Group, 12, rue du 35 ème régiment d'aviation, 69500 Bron, France.

Received: 8 June 2021 Accepted: 20 July 2021

Published online: 17 August 2021

\section{References}

1. Bhattarai S, Framstad T, Nielsen J. Hematologic reference intervals of Danish sows at mid-gestation. Acta Vet Scand. 2019;61. https://doi.org/10.1186/s13 028-019-0451-7.

2. Bhattarai S, Framstad T, Nielsen J. Stillbirths in relation to sow hematological parameters at farrowing: A cohort study. J Swine Health Prod. 2018;26:21522.

3. Tumbleson ME, Scholl E. Hematology and clinical chemistry [Swine, normal values]. Published online 1981.

4. Ježek jožica, Staric J, Nemec M, et al. The influence of age, farm, and physiological status on pig hematological profiles. J Swine Health Prod. 2018;26:72-8.

5. Brissonnier M, Normand $V$, Lebret $A$, et al. Frequency of infection with Mycoplasma suis in gestating sows using qPCR on ten commercial French herds, and impact of the infection on clinical, haematological and biochemical parameters. Porcine Health Manag. 2020;6:13-3. doi:https://doi. org/10.1186/s40813-020-00152-4

6. Štukelj M, Toplak I, Nemec Svete A. Blood antioxidant enzymes (SOD, GPX), biochemical and haematological parameters in pigs naturally infected with porcine reproductive and respiratory syndrome virus. Pol J Vet Sci. 2013;16: 369-76. doi:https://doi.org/10.2478/pjvs-2013-0049.

7. Ventrella D, Dondi F, Barone F, et al. The biomedical piglet: Establishing reference intervals for haematology and clinical chemistry parameters of two age groups with and without iron supplementation. BMC Vet Res. 2016:13. https://doi.org/10.1186/s12917-017-0946-2.

8. Yeom S, Cho S-Y, Park C-G, Lee W-J. Analysis of reference interval and agerelated changes in serum biochemistry and hematology in the specific pathogen free miniature pig. Lab Anim Res. 2012;28:245-53. https://doi. org/10.5625/lar.2012.28.4.245

9. Normand V, Perrin H, Auvigne V, Robert N, Laval A. Anaemia in the sow: A cohort study to assess factors with an impact on haemoglobin concentration, and the influence of haemoglobin concentration on the reproductive performance. Vet Rec. 2012;171:350. doi:https://doi.org/10.113 6/vr.100404

10. Holtkamp DJ, Morrison B, Rowland RR, Snelson H. Terminology for classifying swine herds by porcine reproductive and respiratory syndrome virus status. J Swine Health Prod. 2011;19(1):13.

11. Friedrichs KR, Harr KE, Freeman KP, et al. ASVCP reference interval guidelines: determination of de novo reference intervals in veterinary species and other related topics. Vet Clin Pathol. 2012:41(4):441-53. doi: https://doi.org/10.1111/vcp.12006.

12. Geffré A, Concordet D, Braun J-P, Trumel C. Reference Value Advisor: a new freeware set of macroinstructions to calculate reference intervals with 
Microsoft Excel. Vet Clin Pathol. 2011;40(1):107-12. doi:https://doi.org/1 0.1111/j.1939-165X.2011.00287.x.

13. Thorn C. Hematology of the pig. In: Schalm's veterinary hematology. 6th ed.: 2010:843-851.

14. Bellier S, Cordonnier N. Les valeurs usuelles en hématologie vétérinaire. Revue Francophone des Laboratoires. 2010;2010(420):27-42. https://doi. org/10.1016/S1773-035X(10)70419-6

15. Egbunike GN, Akusu MO. Breed and sex influences on porcine haematological picture under hot humid climatic conditions. Vet Res Commun. 1983;6(1):103-9. doi:https://doi.org/10.1007/BF02214902.

16. Ježek J. The influence of age, farm, and physiological status on pig hematological profiles. JSHAP. 2018;26(2):72-8.

17. Fontaine M, Hamelin N, Martineau GP. Effect of time, storage conditions and mailing on the stability of porcine blood values. Med Vet Quebec. 1987; 17:15-21.

18. Grindem CB. Schalm's Veterinary Hematology, 6th edition. Editors: Douglas J. Weiss, K. Jane Wardrop. Vet Clin Pathol. 2011;40(2):270-270. https://doi. org/10.1111/j.1939-165X.2011.00324.X.

19. Ladinig A. Changes in leukocyte subsets of pregnant gilts experimentally infected with porcine reproductive and respiratory syndrome virus and relationships with viral load and fetal outcome. Vet Res. 2014;45. https://doi. org/10.1186/s13567-014-0128-1.

20. Nielsen J, Vincent IE, Bøtner A, et al. Association of lymphopenia with porcine circovirus type 2 induced postweaning multisystemic wasting syndrome (PMWS). Vet Immunol Immunopathol. 2003;92(3-4):97-111. doi: https://doi.org/10.1016/s0165-2427(03)00031-x.

21. Gauger PC, Lager KM, Vincent AL, et al. Leukogram abnormalities in gnotobiotic pigs infected with porcine circovirus type 2. Vet Microbiol. 2011;154(1-2):185-90. doi:https://doi.org/10.1016/j.vetmic.2011.06.016.

22. Zaleski HM, Hacker RR. Variables related to the progress of parturition and probability of stillbirth in swine. Can Vet J. 1993;34(2):109-13.

23. Bhattarai S. Stillbirths in relation to sow hematological parameters at farrowing: A cohort study. JSHAP. 2018;26(4):215-22.

\section{Publisher's Note}

Springer Nature remains neutral with regard to jurisdictional claims in published maps and institutional affiliations.

Ready to submit your research? Choose BMC and benefit from:

- fast, convenient online submission

- thorough peer review by experienced researchers in your field

- rapid publication on acceptance

- support for research data, including large and complex data types

- gold Open Access which fosters wider collaboration and increased citations

- maximum visibility for your research: over $100 \mathrm{M}$ website views per year

At $\mathrm{BMC}$, research is always in progress.

Learn more biomedcentral.com/submissions 